\title{
Assessing trap and lure effectiveness for the monitoring of Sirex noctilio
}

\author{
Brett P. Hurley*, Jeff Garnas* and Miriam F. Cooperband \\ * Department of Zoology and Entomology, Forestry and Agricultural Biotechnology Institute (FABI), University of Pretoria, Cnr Lynnwood and \\ University Roads, Hatfield, 0083, Pretoria, South Africa and ${ }^{\dagger}$ Otis Laboratory, USDA-APHIS-PPQ-CPHST, 1398 W. Truck Road, Buzzards Bay, MA \\ 02542, U.S.A.
}

\begin{abstract}
Lure-baited traps are an important tool for monitoring the spread and establishment of the Sirex woodwasp Sirex noctilio. The utility of these traps, however, is limited in areas with low wasp populations as a result of the reliance on a plant volatile (kairomone) lure in the absence of an identified pheromone. Knowledge of the optimal trap type and deployment strategy is also lacking.

2 We tested the effectiveness of a putative pheromone in baited traps, by means of a series of field trials in South Africa, over a 3-year period. We also examined the influence of lure type, trap type and trap height on capture success.

3 The pheromone was found to be ineffective as an attractant under South African field conditions for both male and female wasps. Lure type, trap type and trap height were found to have little to no effect on female wasp catch. Given the moderately strong responses to the blend under wind tunnel and laboratory conditions, we suggest possible aspects of the biology and life history of $S$. noctilio that may influence lure effectiveness.

4 The traditional black intercept panel traps with kairomone lure remains the best trap for S. noctilio, at least where populations are high.
\end{abstract}

Keywords Insect detection and monitoring, intercept panel traps, kairomone, pheromone.

\section{Introduction}

Accurate information on the abundance and spread of alien invasive species is required to inform management decisions and to predict and minimize potential detrimental effects to natural and human landscapes. For alien invasive forest insect species, traps baited with either tree stress volatiles or synthetic pheromones that closely mimic those produced and detected by the insects themselves are among the most effective tools for monitoring spread and establishment (Brockerhoff et al., 2006; Witzgall et al., 2010; Nadel et al., 2012). Trap design and deployment strategy is often target insect-specific, with myriad variables of trap shape, size, colour, position and timing of deployment being critical to success. Successful examples of forest insect pests whose spread has been monitored with lure-based traps include the red turpentine beetle Dendroctonus valens (Erbilgin et al., 2008), the emerald ash borer Agrilus planipennis (Crook \& Mastro, 2010), gypsy moth Lymantria dispar (Sharov et al., 1997) and pine processionary moth Thaumetopoea pityocampa (Athanassiou et al., 2007), amongst many others. However,

Correspondence: Brett P. Hurley. Tel.: +27 12 4205822; fax: +27 12 4203960; e-mail: brett.hurley@up.ac.za despite the importance of lure-based traps for monitoring the spread and establishment of forest insect pests, this tool is not available or well developed for some important invasive species.

The Sirex woodwasp Sirex noctilio is one such invasive insect pest for which lure-based traps for monitoring require further development. Native to Eurasia, this insect has been accidentally introduced to many parts of the southern hemisphere and, more recently, to the U.S.A. and Canada (Hoebeke et al., 2005; de Groot et al., 2006; Hurley et al., 2007). Females of the Sirex woodwasp attack primarily stressed or weakened Pinus trees, injecting a phytotoxic mucus together with inoculum of an obligate fungal symbiont (Amylostereum areolatum), resulting in rapid tree death, usually within a few months (Talbot, 1977; Bordeaux \& Dean, 2012). In the southern hemisphere, where $S$. noctilio was first detected in the 1900s, it has caused widespread mortality and considerable economic losses to non-native pine forestry (Hurley et al., 2007). Although it remains a significant threat to pine production in many areas, losses incurred as a result of established $S$. noctilio populations have been offset by management strategies, specifically silvicultural methods aiming to reduce stress in the stands and the introduction of various biological control agents. Accurate knowledge of the current 
and changing distribution of $S$. noctilio is crucial for ensuring appropriate management. This applies particularly to North America, north-eastern Australia, Chile and other areas where S. noctilio is still spreading to new areas (Carnegie et al., 2005; Beéche et al., 2012; Dodds \& de Groot, 2012), and where early detection in these new areas can assist management strategies.

Various methods have been used to detect and monitor populations of $S$. noctilio as it has spread through its invaded range. Ground and aerial surveys have been widely used in Australia, South America and South Africa (Carnegie et al., 2008; Beéche et al., 2012; Hurley et al., 2012; Klasmer \& Botto, 2012), although they are time consuming and costly when conducted on a large scale (Bashford \& Madden, 2012). More recently, satellite imagery has been used to monitor $S$. noctilio populations (Ismail \& Mutanga, 2011), although this approach depends on differences in spectral reflectance correlated with tree stress/decline and is not specifically linked to infestation by $S$. noctilio. In addition, aerial methods are inefficient with respect to detecting low density populations of $S$. noctilio where infestations largely occur in subdominant trees obscured by the canopy when viewed from above.

Other approaches used to monitor and detect $S$. noctilio include the use of herbicide or mechanically-killed trap trees (Madden, 1971), as well as traps baited with kairomone lures based on plant stress volatiles (Bashford, 2008). The trap tree approach is successful with respect to detecting $S$. noctilio at low densities and can be co-utilized to introduce the parasitic nematode Deladenus (=Beddingia) siricidicola (Bedding \& Iede, 2006), although this method is expensive and highly labour intensive. Traps baited with kairomone lures have experienced variable success that appears to be linked to differences in population densities throughout the wasp's invasive range. For example, in South Africa, where S. noctilio populations are high, plant volatile lures are reasonably successful, whereas, in mixed stands of North America where wasp densities are comparatively low, traps appear to be less efficient (Dodds \& de Groot, 2012). In areas with native pine, the by-catch of native siricids and other bark and wood-feeding insects is also a concern.

In 2010, extensive gas chromatography-electroantennographic detection (GC-EAD) investigations and subsequent laboratory assays identified a putative male-produced aggregation pheromone with the potential for use as a field attractant for $S$. noctilio. The compounds [major component: (Z)-3-decenol; minor components: (Z)-4-decenol and $(E, E)$-2,4-decadienal] induced a significant positive response in both males and females using Y-tube olfactometers and a wind tunnel (Cooperband et al., 2012). The present study aimed to test the effectiveness of a synthetic pheromone lure developed incrementally over 3 years by Cooperband et al. (2012). In the first year of field trials, only the main pheromone component had been discovered and the presence of minor components was still being investigated. The present study was carried out in three consecutive years (2010-2012) in pulp plantations of Pinus patula in South Africa, largely as a result of the consistently high densities of wasps and knowledge of the distribution, abundance and phenology of the insect in this area. In 2011 and 2012, we also varied lure type, trap type and height in the canopy in an effort to maximize capture rate, in part based on the results obtained in 2010 .

\section{Materials and methods}

\section{Field sites and overall general approach}

Trap trials were established over a 3-year period from 2010 to 2012. In each year, the trap trial was established at three different sites near Waterval Boven in Mpumalanga province $\left(25.74^{\circ} \mathrm{S}, 29.83^{\circ} \mathrm{E}\right)$. The trap trial in 2010 included an additional three sites near Mthata in the Eastern Cape province $\left(30.54^{\circ} \mathrm{S}\right.$, $\left.28.91^{\circ} \mathrm{E}\right)$. Each site was located in $10-15$-year-old plantations of P. patula and separated by between 10 and $50 \mathrm{~km}$. In each year, a randomized complete block design was used but the number and type of treatments differed between years (Table 1). In all years, the plant stress volatile (herein 'kairomone') lure known to be effective as an attractant to S. noctilio in South African plantations was used as a positive control and was used in conjunction with the putative pheromone. Additionally, we included trap blanks (no chemical component) to control for the visual effect of the different trap types together with the possibilities of random intercepts as wasps fly through the stands.

\section{Year-by-year experimental design}

For the 2010 trial, each site contained 14 treatments with five replicate traps per treatment. Black intercept panel traps (70 total per site, 420 total) were hung on trees at a height of $2.5 \mathrm{~m}$ in a $7 \times 10$ grid, maintaining a distance of $20 \mathrm{~m}$ between traps. Treatments included the major pheromone component [(Z)-3-decenol; identified by Cooperband et al. (2012)] at four concentrations $(0,0.3,3$ and $30 \mathrm{mg})$, a suspected minor compound at that time (nonanoic acid), present at $1 \%$ of the concentration of the major component or absent, and the kairomone present (at $30 \mathrm{mg}$ ) or absent (Table 1). When the major pheromone component (Z)-3-decenol was at $0 \mathrm{mg}$, nonanoic acid was also absent. Rubber septa were used as the release devices for the two-compound blend. The kairomone lure was the lure developed in previous collaborative trials with USDA-APHIS and consisted of

Table 1 Summary of the treatments tested for the trap trial over the 3-year period. Each treatment was replicated five times at each site

\begin{tabular}{|c|c|c|c|c|}
\hline Year & Trap type & Treatment & $\begin{array}{l}\text { No. of } \\
\text { treatments }\end{array}$ & Levels \\
\hline \multirow[t]{3}{*}{2010} & - & Major component & 4 & $0,0.3,3$ and $30 \mathrm{mg}$ \\
\hline & & Minor component & 2 & Yes/No \\
\hline & & Plant volatile & 2 & Yes/No \\
\hline \multirow[t]{6}{*}{2011} & Panel traps & Pheromone lure & 3 & $0,0.1$ and $1 \mathrm{mg}$ \\
\hline & & Plant volatile lure & 2 & Yes/No \\
\hline & & Trap height & 2 & Low/high \\
\hline & Bottle traps & Pheromone lure & 2 & 0 and $1 \mathrm{mg}$ \\
\hline & & Plant volatile lure & 2 & Yes/No \\
\hline & & Trap height & 1 & High only \\
\hline \multirow[t]{4}{*}{2012} & Black traps & Pheromone lure & 3 & $\begin{array}{l}\text { Septa } 1 \text { mg; Flexi } \\
2 \text { mg; Flexi } 8 \text { mg }\end{array}$ \\
\hline & & Plant volatile lure & 2 & Yes/No \\
\hline & Clear traps & Pheromone lure & 1 & Septa $1 \mathrm{mg}$ \\
\hline & & Plant volatile lure & 2 & Yes/No \\
\hline
\end{tabular}


a blend of (+)- $\alpha$-pinene $(12.5 \%)(-)-\alpha$-pinene $(12.5 \%)$, (-)- $\beta$-pinene $(25.0 \%),(+)-3$-carene $(30.0 \%),(+)$-camphene $(5.0 \%), \quad \beta$-myrcene $(10.0 \%), \quad(+)$-limonene $(2.5 \%)$ and (-)-limonene $(2.5 \%)$. This is the same lure used in the South African National Sirex Monitoring program [Insect Science (Pty) Ltd, Tzaneen, South Africa]. Plastic bottles (clear bottle: length $15 \mathrm{~mL}$, thickness $650 \mu \mathrm{m}$, in a polyethylene bag) were used as the release device for the kairomone lure.

Each site in the 2011 trial contained 16 treatments, with five replicates of each treatment. Black intercept panel traps (80 total per site, 240 total) were hung on trees at a height of $2.5 \mathrm{~m}$ in an $8 \times 10$ grid, maintaining a distance of $20 \mathrm{~m}$ between traps. Treatments consisted of the new three-component pheromone lure, with (Z)-3-decenol, (Z)-4-decenol and (E,E)-2-4-decadienal at $100: 1: 1$, respectively (Cooperband et al., 2012), at three dosages $(0,0.1$ and $1 \mathrm{mg})$; the presence and absence of the same kairomone lure used in the 2010 trial; two trap designs (panel and clear jar); and two trap heights (2.5 and $8 \mathrm{~m}$ above ground level) (Table 1).

The new pheromone lures used in the 2011 trial consisted of the same major component as that used in the 2010 trial but excluded nonanoic acid and, instead, included two new potential minor components that were identified in the Otis Laboratory (USDA-APHIS) in 2011 using GC-EAD, gas chromatography-mass spectrometry and Y-tube bioassays (Cooperband et al., 2012). The two trap designs tested were traditional black intercept panel traps and a new clear jar trap design, constructed from rectangular plastic jars (64-oz; PVC Pinch Grip-It Jars, US Plastic Corp., Lima, Ohio) (Sarvary et al., 2014). The clear jar design was developed in response to the observation that, although both sexes were attracted to pheromone lures in wind tunnel experiments, females flew into the targets made of black panel material, whereas males were able to avoid or land on the targets made of black panel material, potentially explaining why males were rarely trapped in collection buckets in field trials (Cooperband et al., 2012). Prototypes were developed at APHIS and showed promise in wind tunnel experiments in catching S. noctilio males (Sarvary et al., 2014). Given the logistical and budget constraints, all combinations of lures and trap height were used only for the black intercept panel traps. We excluded the 0.1-mg dosage of the pheromone lure and the low trap height for the newly-designed clear jar traps (Table 1).

The 2012 trap trial contained one 60-trap site with 12 treatments and two 40-trap sites with eight treatments. Each treatment was replicated five times, giving a total of 140 traps. Intercept panel traps were hung on trees at a height of $2.5 \mathrm{~m}$ in a $6 \times 10$ grid or $4 \times 10$ grid, maintaining $20 \mathrm{~m}$ between traps. Treatments for the 60-trap site included the same three-component pheromone blend used in the 2011 trial but with three lure types and dosages (septa lure $1 \mathrm{mg}$, Flexlure $2 \mathrm{mg}$, Flexlure $8 \mathrm{mg}$ ) (Flexlure, Contech Enterprises Inc., Canada), the presence and absence of kairomone lure, and intercept trap colour (black and clear). Clear intercept traps were only used with the septa lure and kairomone and only at a single site as a result of the limited numbers of clear traps available. The same treatments were used in the 40-trap sites, excluding the treatments with the clear intercept traps.
In the 3 years of field studies, the major pheromone component was synthesized by Dr Tappey Jones (Virginia Military Institute, Lexington, Virginia) as described in Cooperband et al. (2012), and this process resulted in the presence of a small amount of the $(E)$-3-decenol isomer. In the third year, the $(Z)$-3-decenol was sent to Contech to attempt further purification. In 2010, 2011 and 2012, the amount of (E)-3-decenol in 100 parts of $(Z)-3$-decenol used in lures was $0.6 \%, 0.8 \%$ and $0.3 \%$, respectively.

\section{Data collection}

The monitoring period of the traps included the peak emergence of $S$. noctilio in the trial areas, based on historical data. For the 2010 trial, the traps were monitored for 5 weeks; from the week of 8-12 November until 6-10 December. For the 2011 and 2012 trials, the traps were monitored for 6 weeks; from the weeks of 24-28 October until 28 November to 2 December in 2011 and 5-9 November until 10-14 December in 2012. Traps were checked weekly. Wasps were counted, sexed and removed from traps, and the buckets re-filled with soapy water. Lures were replaced at the end of the third week of the monitoring period, based on the manufacturer's recommendations.

\section{Statistical analysis}

Mean female trap catch across the sampling weeks were analyzed using separate analysis of variance (ANOvA) models for each year. The dependent variable(s) were $\log (x+1)$ transformed for 2010 and 2011 data and square-root transformed in the 2012 data to conform to model assumptions of normality and homogeneity of variance. As a result of very low male catches, only data from female catches were analyzed statistically. Preliminary tests in each year revealed the absence of a block effect and so block was discarded from reported models. We also performed a repeated measures ANOVA on weekly time series data. Results from the repeated measures analysis were qualitatively similar to those based on mean trap catch. For simplicity, all trends reported are based on mean catch across weeks.

For the 2010 data, because the design was slightly unbalanced (i.e. the minor component was not tested in the absence of the major component), we tested the contribution of the minor component using a subset of data comprising a fully factorial experiment (i.e. by removing trap data from treatments where the major component was absent). We also considered the effects of region (north versus south) and site as a nested factor within region. In the 2011 data, clear jar trap catch was not included in the statistical analyses as a result of negligible capture rates (10 wasps across all sites and weeks). For the 2012 trap trial, clear intercept panels traps were placed only in a single site and were analyzed using trap type (clear versus black), kairomone (presence/absence) and lure (septa versus none) in a subsetted $2 \times 2 \times 2$ factorial design. No transformation was necessary in this subset of the data. The black intercept panel trap data were treated separately as a $3 \times 2 \times 4$ factorial ANOVA. All statistical analyses were performed using R (R Core Team, 2013). 


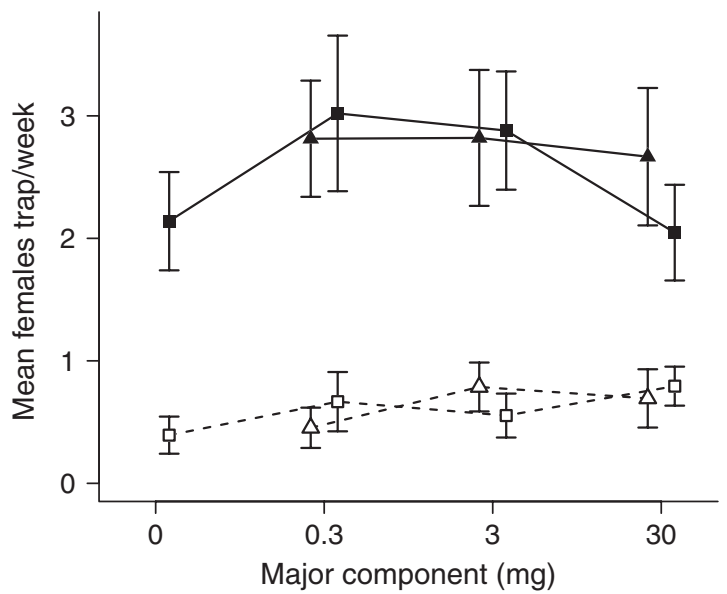

Figure 1 Mean trap capture of female Sirex noctilio from 2010 trap trial by major component [(Z)-3-decenol], concentration, presence versus absence of $1 \%$ nonanoic acid (triangles versus squares) and presence versus absence of kairomone lure (closed symbols, solid lines versus open symbol, dashed lines). Error bars indicate the standard error.

\section{Results}

A total of 12464 S. noctilio were caught in the traps over the 3 years of trap trials (3423 in 2010, 2212 in 2011 and 6827 in 2012). Of these, only 161 were males, representing $1.3 \%$ of the total wasps caught. This number is especially low considering the male bias in the population (measured as $6.5: 1$ male : female ratio in the region in 2012; B. P. Hurley, unpublished data).

In the 2010 trial, trap catch varied significantly by site (nested within region; $F_{4,380}=191.2 ; P<0.0001$ ) but not region $\left(F_{1,4}=0.14 ; P=0.73\right)$. Among the lure combinations tested, wasps showed by far the strongest response to the kairomone lure $\left(F_{1,380}=495.4 ; P<0.0001\right)$ (Fig. 1$)$, irrespective of pheromone treatment. This effect was consistent both within and across weeks. The major pheromone component showed no significant main effect on wasp catch $\left(F_{3,405}=1.97 ; P=0.12\right)$ in the 2010 trial. The major pheromone component did interact marginally with the kairomone lure $\left(F_{3,405}=2.6 ; P=0.05\right)$; trap catch increased more or less linearly from a concentration of 0 to $30 \mathrm{mg}$ but only in the absence of the kairomone. Planned linear contrasts revealed that, where the kairomone was absent, the major pheromone component was no more attractive than the control at a concentration of $0.3 \mathrm{mg}\left(t_{405}=1.19 ; P=0.12\right)$, although lures containing 3 and $30 \mathrm{mg}$ attracted more wasps than the lures without the major pheromone component $\left(t_{405}=1.88\right.$; $P=0.03$ and $t_{405}=2.38 ; P=0.009$, respectively). However, the biological significance of these differences was questionable (least squares means for treatments $0,0.3,3.0$ and $30.0 \mathrm{mg}$ : 0.24, $0.35,0.46$ and 0.53 wasps per trap per week, respectively, versus $1.57,1.96,1.95$ and 1.58 wasps in the presence of kairomone). The nonanoic acid component did not appear to influence lure attractiveness $\left(F_{1,405}=0.003 ; P=0.96\right)$.

In 2011 , mean wasp catch varied by site $\left(F_{2,144}=106.7\right.$; $P<0.0001$ ), with two sites yielding the majority of the wasps collected in this trial (1108 females and 11 males and 917 females and five males, respectively). Wasp catch peaked in weeks 4 and 5 (14-25 November) at these two sites (554 and 397 wasps,

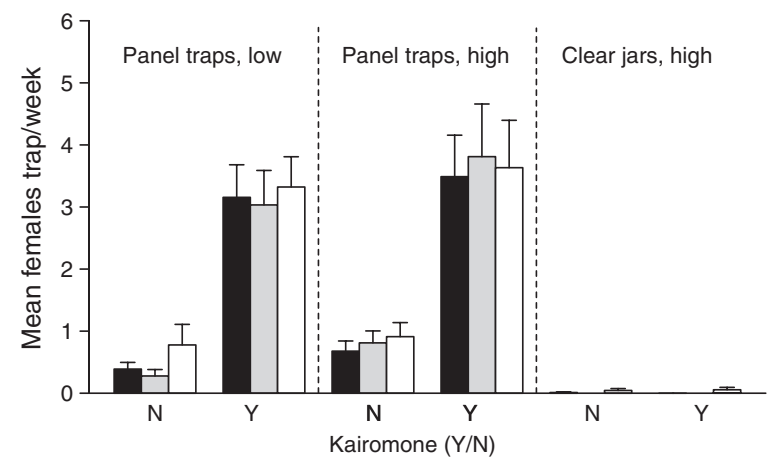

Figure 2 Mean trap capture of female Sirex noctilio for 2011 trap trial by treatment. Black bars correspond to the absence of the three-component pheromone blend, and grey and white bars correspond to low and high $(0.1$ and $1.0 \mathrm{mg})$ concentrations, respectively. Clear jar traps were only tested at two sites, at zero and high pheromome concentrations and at $8 \mathrm{~m}$ above ground level (high), and caught a total of 10 wasps during the course of the experiment.

respectively). The clear jar traps were ineffective under field experimental conditions, with only 10 females and no males caught in the 60 traps over the 6 weeks. For intercept panel traps, female wasp catches showed by far the strongest response to the kairomone lure $\left(F_{1,144}=294.5 ; P<0.0001\right)$ (Fig. 2), with trap catches significantly higher when the kairomone was present. Pheromone concentration showed no significant influence on female catch $\left(F_{2,144}=2.2 ; P=0.10\right)$. Trap height on the other hand did significantly influence capture rates $\left(F_{1,144}=4.5\right.$; $P=0.04)$; traps placed at $8 \mathrm{~m}$ attracted more females than those placed at $2 \mathrm{~m}$, although overall differences were minor (1200 and 986 wasps, respectively, across sites and panel trap treatments). Trap height also interacted with site $\left(F_{2,144}=8.3 ; P<0.001\right)$ and kairomone lure $\left(F_{1,144}=8.1 ; P=0.005\right)$ but biological differences were minor. Ten males were collected in the higher traps versus six in the low traps.

For the 2012 trial, trap type influenced female wasp catch $\left(F_{1,32}=20.5 ; P<0.0001\right)$ (Fig. 3), as did kairomone lures $\left(F_{1,32}=35.9 ; \quad P<0.0001\right) \quad$ (Fig. 3$)$, with black traps and kairomone lures attracting significantly more wasps. There was also a significant trap type by kairomone lure interaction $\left(F_{1,32}=16.6 ; P=0.0002\right)$ with kairomone lures strongly

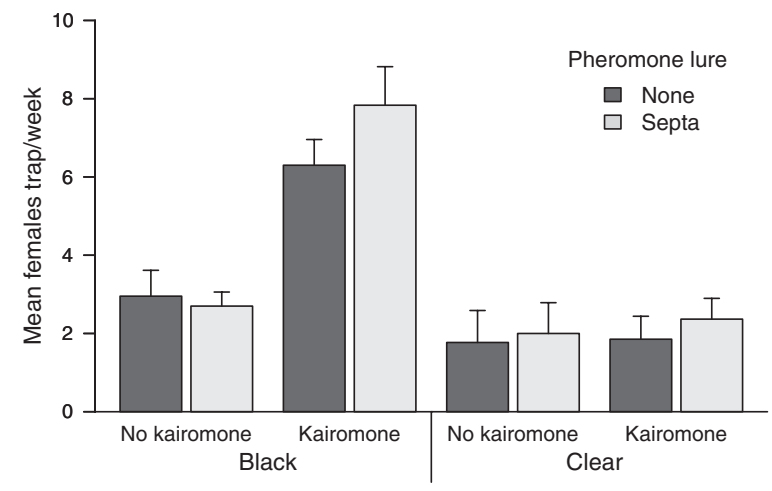

Figure 3 Comparision of the number of female Sirex noctilio caught between black and clear panel traps for the 2012 trap trial. 


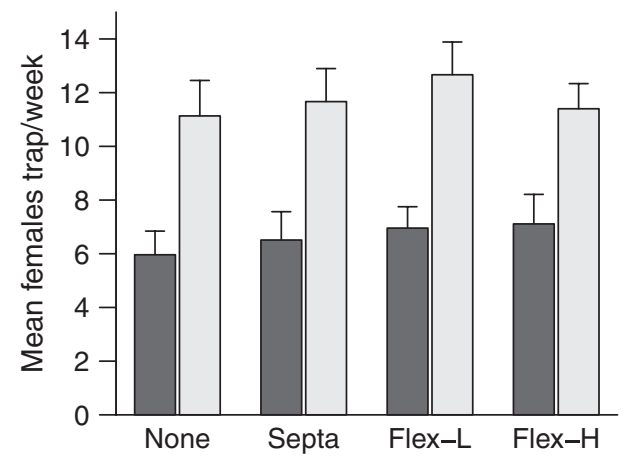

Figure 4 Comparison of the number of Sirex noctilio wasps caught by lure type and kairomone lure presence (light bars) or absence (dark bars) in the 2012 trap trial. Flex-L and Flex-H refer to 'Flex lures' (Contech Enterprises Inc.) infused with 2 and $8 \mathrm{mg}$ of pheromone blend, respectively, compared with the $1 \mathrm{mg}$ of septa.

improving trap catch but only in the black intercept panel traps. The presence or absence of the septa lures had no effect on trap catch at this site $\left(F_{1,32}=0.07 ; P=0.79\right)$. For black intercept panel traps across all three sites, we found a significant effect of site $\left(F_{2,96}=16.5 ; P<0.0001\right)$ and kairomone lures $\left(F_{1,96}=103.9 ; P<0.0001\right)$ on mean female trap catch across weeks (Fig. 4). There was no significant effect of pheromone lure as a main effect $\left(F_{3,96}=1.4 ; P<0.25\right)$ and the pheromone lure did not interact significantly with any other treatment. These results were equivalent in all weeks.

\section{Discussion}

The present study investigated the efficacy of a novel synthetic pheromone to trap $S$. noctilio along with other factors hypothesized to influence baited trap performance, namely trap design, transparency and placement in the canopy. This was accomplished by means of a series of replicated trapping trials over a 3 -year period. The results clearly indicate that the pheromone lures were ineffective at attracting $S$. noctilio under South African field conditions and with the trap designs employed. Kairomone lures were confirmed as effective attractants. Factors such as pheromone lure concentration, panel transparency and placement in the canopy had little or no effect on wasp captures. The clear jar traps were entirely ineffective. When baited with the kairomone lures, black trap colour greatly enhanced trap capture compared with clear traps.

There are several potential explanations for the apparent lack of pheromone lure attractiveness in our trials. First, it is possible that the identity and/or ratios of the major and minor components are incorrect or additional components are required. This is particularly relevant for 2010, prior to the discovery of the two minor components. It is possible that the amount of $(E)$-3-decenol, a known inhibitor when added at $1 \%$ (Cooperband et al., 2012), could have interfered with attraction in 2011 when it was present at $0.8 \%$ of the major compound. However, given the positive electroantennographic response and positive orientation behaviour in choice assays using North American wasps and the same lures (Cooperband et al., 2012; Sarvary et al., 2014), other hypotheses warrant consideration.
Alternate hypotheses to explain the ineffectiveness of the pheromone lure include that pheromones and/or pheromone receptors are different in southern hemisphere $S$. noctilio populations, which originated from a distinct introduction relative to North American populations (Boissin et al., 2012). GC-EAD work to evaluate this possibility is currently in progress. The innate behaviour of male wasps also could have limited male trap catch. Males were observed in wind tunnel experiments to land on pheromone-baited targets instead of bumbling into them (M. F. Cooperband, personal observation), and were captured by the pheromone-baited clear jar traps in wind tunnel studies, where they were also found to be strongly positively phototactic (Sarvary et al., 2014). The phototactic behaviour may explain why alternative trap designs to circumvent this potential problem were also unsuccessful at capturing males in pine plantations at heights of 2.3 and $8 \mathrm{~m}$, which are well below the canopy. Finally, with regard to females, pheromone lure attractiveness may be dependent on the age and mating status, which, given the mating behaviour and life history of S. noctilio, is likely to complicate the use of pheromone traps.

Pheromone production, perception and behavioural response can be influenced by factors such as insect age and mating status (Barrozo et al., 2011). As a result of the apparently strong phototactic response of wasps (Sarvary et al., 2014), emerging male and female $S$. noctilio fly to the tree canopy where they form mating swarms (Morgan \& Stewart, 1966; Madden, 1988). If this behaviour over-rides the response to chemical volatiles, wasps may leave the understory irrespective of the pheromones present. After mating, males may continue to be positively phototactic and seek additional mates above the canopy, and females are likely to respond most strongly to host volatiles and visual cues (Madden, 1968; Sarvary et al., 2014). Although we have little empirical data to support this hypothesis to date, over $70 \%$ of spermatheca dissected from trapped females contained sperm (A. L. Wooding, unpublished data), which is consistent with the idea that behaviour and timing may influence trap catch. Anecdotally, males were present in large numbers at the times of peak capture but, by and large, were found on the forest floor, presumably having spent the bulk of their energetic reserves. More direct measurements of the context dependence of attraction of pheromones in the laboratory or field enclosures could shed more light on these unresolved questions.

The influence of trap height, trap design and trap colour was also investigated because it was suggested that these might increase wasp catch, specifically male wasps. Such factors have been recorded to significantly influence trap catch in other forest insects of economic importance, including the oak processionary moth Thaumetopoea processionea (Williams et al., 2013), pine moth Thaumotopoea pityocampa (Athanassiou et al., 2007), emerald ash borer A. planipennis (Ryall et al., 2012), and generally for cerambycid beetles and siricid wasps (Morewood et al., 2002; Graham et al., 2012). However, the influence of these factors appears to be highly specific to the target species (Brar et al., 2012). In the present study, the marginally higher trap efficiency at 8 versus $2 \mathrm{~m}$ is not sufficiently large to warrant the additional expense and complexity of placing and monitoring traps at mid-canopy.

In summary, traditional black intercept panel traps with kairomone (plant volatile) lures in use in South Africa from 
2004 onward remain the best choice for trapping studies, at least where populations are high. The tested pheromone blend was not an effective lure for catching $S$. noctilio males or females with the current trapping or release system, nor did it synergize the kairomone lure. Placing traps higher in the tree may slightly increase wasp catch but, given the logistical challenge and costs associated with placing and monitoring at approximately $8 \mathrm{~m}$, this approach does not appear to be worthwhile. Improving trap design may be necessary to increase the catch of male wasps, and further testing of the context-dependency of the attractiveness of synthesized pheromones to $S$. noctilio, together with an integrated understanding of wasp biology, is warranted.

\section{Acknowledgements}

The present study was funded by the USDA APHIS PPQ CPHST. We thank the South African forestry companies Sappi and PG Bison for permission to conduct the field trials on their land. We specifically thank Marcel Verleur (Sappi), Richard McCarthy (Sappi), Julian Chan (PG Bison) and Philip Croft (ICFR) for various logistical support. We also thank Denzil Lawrie and his team, as well as the numerous students from FABI, University of Pretoria, for assistance with setting up and monitoring the trap trials over the 3-year period. We thank Ashley Hartness for help with the preparation of materials to be tested; Tappey Jones and J. P. Lafontaine for their work on the pheromone; and John Borden and Contech for providing Flexlures to test. Mention of a commercial product does not constitute an official endorsement or approval by the USDA of any product or service to the exclusion of others that may be suitable.

\section{References}

Athanassiou, C.G., Kavallieratos, N.G., Gakis, S.F., Kyrtsa, L.A., Maxomenos, B.E. \& Gravanis, F.T. (2007) Influence of trap type, trap color, and trapping location on the capture of the pine moth, Thaumetopoea pityocampa. Entomologia Experimentalis et Applicata, 122, 117-123.

Barrozo, R.B., Jarriault, D., Deisig, N. et al. (2011) Mating-induced differential coding of plant odour and sex pheromone in a male moth. European Journal of Neuroscience, 33, 1841-1850.

Bashford, R. (2008) The development of static trapping systems to monitor for wood-boring insects in forestry plantations. Australian Forestry, 71, 236-241.

Bashford, R. \& Madden, J.L. (2012). The use of kairomone lures for the detection of Sirex noctilio in susceptible Pinus radiata plantations in Australia. The Sirex Woodwasp and its Fungal Symbiont: Research and Management of a Worldwide Invasive Pest (ed. by B. Slippers, P. de Groot and M. J. Wingfield), pp. 159-166. Springer, The Netherlands.

Bedding, R.A. \& Iede, E.T. (2006) Application of Beddingia siricidicola for Sirex woodwasp control. Nematodes as Biocontrol Agents (ed. by P. S. Grewal, R. Ehlers and D. I. Shapiro-Ilan), pp. 385-400. CAB International, U.K.

Beéche, M., Lanfranco, D., Zapata, M. \& Ruiz, C. (2012) Surveillance and control of the Sirex woodwasp. The Sirex Woodwasp and its Fungal Symbiont: Research and Management of a Worldwide Invasive Pest (ed. by B. Slippers, P. de Groot and M. J. Wingfield), pp. 229-237. Springer, The Netherlands.

Boissin, E., Hurley, B.P., Wingfield, M.J. et al. (2012) Retracing the routes of introduction of invasive species: the case of the Sirex noctilio woodwasp. Molecular Ecology, 23, 5728-5744.
Bordeaux, J.M. \& Dean, J.F.D. (2012) Susceptibility and response of pines to Sirex noctilio. The Sirex Woodwasp and its Fungal Symbiont: Research and Management of a Worldwide Invasive Pest (ed. by B. Slippers, P. de Groot and M. J. Wingfield), pp. 31-50. Springer, The Netherlands.

Brar, G.S., Capinera, J.L., McLean, S., Kendra, P.E., Poetz, R.C. \& Peña, J.E. (2012) Effect of trap size, trap height and age of lure on sampling Xyleborus glabratus Coleoptera: Curculionidae: Scolytinae), and its flight periodicity and seasonality. Florida Entomologist, 94, 1003-1011.

Brockerhoff, E.G., Liebhold, A.M. \& Jactel, H. (2006) The ecology of forest insect invasions and advances in their management. Canadian Journal of Forest Research, 36, 263-268.

Carnegie, A.J., Elderidge, R.H. \& Waterson, D.G. (2005) History and management of Sirex wood wasp in pine plantations in New South Wales, Australia. New Zealand Journal of Forestry Science, 35, 3-24.

Carnegie, A.J., Cant, R.G. \& Eldrigdge, R.H. (2008) Forest health surveillance in New South Wales, Australia. Australian Forestry, 71, 164-176.

Cooperband, M.F., Böröczky, K., Hartness, A., Jones, T.H., Zylstra, K.E., Tumilinson, J.H. \& Mastro, V.C. (2012) Male-produced pheromone in the European woodwasp, Sirex noctilio. Journal of Chemical Ecology, 38, 52-62.

Crook, D.J. \& Mastro, V.C. (2010) Chemical ecology of the emerald ash borer Agrilus planipennis. Journal of Chemical Ecology, 36, 101-112.

Dodds, K.J. \& de Groot, P. (2012) Sirex, surveys and management: challenges of having Sirex noctilio in North America. The Sirex Woodwasp and its Fungal Symbiont: Research and Management of a Worldwide Invasive Pest (ed. by B. Slippers, P. de Groot and M. J. Wingfield), pp. 265-286. Springer, The Netherlands.

Erbilgin, N., Mori, S.R., Sun, J.H. et al. (2008) Response to host volatiles by native and introduced populations of Dendroctonus valens (Coeoptera: Curculionidae, Scolytinae) in North America and China. Journal of Chemical Ecology, 33, 131-146.

Graham, E.E., Poland, T.M., McCullough, D.G. \& Millar, J.G. (2012) A comparison of trap type and height for capturing cerambycid beetles (Coleoptera). Journal of Economic Entomology, 105, 837-846.

de Groot, P., Nystrom, K. \& Scarr, T. (2006) Discovery of Sirex noctilio (Hymenoptera: Siricidae) in Ontario, Canada. The Great Lakes Entomologist, 39, 49-53.

Hoebeke, E.R., Haugen, D.A. \& Haack, R.A. (2005) Sirex noctilio: discovery of a Palearctic siricid woodwasp in New York. Newsletter of the Michigan Entomological Society, 50, 24-25.

Hurley, B.P., Slippers, B. \& Wingfield, M.J. (2007) A comparison of control results for the alien invasive woodwasp, Sirex noctilio, in the southern hemisphere. Agricultural and Forest Entomology, 9, $159-171$.

Hurley, B.P., Croft, P., Verleur, M., Wingfield, M.J. \& Slippers, B. (2012) The control of the Sirex woodwasp in diverse environments: the South African experience. The Sirex Woodwasp and its Fungal Symbiont: Research and Management of a Worldwide Invasive Pest (ed. by B. Slippers, P. de Groot and M. J. Wingfield), pp. 247-264. Springer, The Netherlands.

Ismail, R. \& Mutanga, O. (2011) Discriminating the early stages of Sirex noctilio infestation using classification tree ensembles and shortwave infrared bands. International Journal of Remote Sensing, 32, 4249-4266.

Klasmer, P. \& Botto, E. (2012) The ecology and biological control of the woodwasp Sirex noctilio in Patagonia, Argentina. The Sirex Woodwasp and its Fungal Symbiont: Research and Management of a Worldwide Invasive Pest (ed. by B. Slippers, P. de Groot and M. J. Wingfield), pp. 203-216. Springer, The Netherlands.

Madden, J.L. (1968) Physiological aspects of host tree favourability for the woodwasp, Sirex noctilio F. Proceedings of the Ecological Society of Australia, 3, 147-149. 
Madden, J.L. (1971) Some treatments which render Monterey pine (Pinus radiata) attractive to the wood wasp Sirex noctilio F. Bulletin of Entomological Research, 60, 467-472.

Madden, J.L. (1988) Sirex in Australasia. Dynamics of Forest Insect Populations. Patterns, Causes, Implications (ed. by A. A. Berryman), pp. 407-429. Plenum Press, New York, New York.

Morewood, W.D., Hein, K.E., Katinic, P.J. \& Borden, J.H. (2002) An improved trap for large wood-boring insects, with special reference to Monochamus scutellatus (Coleoptera: Cerambycidae). Canadian Journal of Forest Research, 32, 519-525.

Morgan, D. \& Stewart, N.C. (1966) The biology and behaviour of the woodwasp Sirex noctilio F. in New Zealand. Transactions of the Royal Society of New Zealand, Zoology, 7, 195-204.

Nadel, R.L., Wingfield, M.J., Scholes, M.C., Lawson, S.A. \& Slippers, B. (2012) The potential for monitoring and control of insect pests in southern hemisphere forest plantations using semiochemicals. Annals of Forest Science, 69, 757-767.

R Core Team (2013) R: A Language and Environment for Statistical Computing. R Foundation for Statistical Computing. [WWW document]. URL http://www.R-project.org/ [accessed on 17 July 2013], Austria.

Ryall, K.L., Silk, P.J., Mayo, P. et al. (2012) Attraction of Agrilus planipennis (Coleoptera: Buprestidae) to a volatile pheromone: effects of release rate, host volatile, and trap placement. Environmental Entomology, 41, 648-656.

Sarvary, M.A., Cooperband, M.F. \& Hajek, A.E. (2014) The importance of olfactory and visual cues in developing better monitoring tools for Sirex noctilio (Hymenoptera: Siricidae). Agricultural and Forest Entomology, 17, 29-35.

Sharov, A.A., Liebhold, A.M. \& Roberts, E.A. (1997) Methods for monitoring the spread of gypsy moth (Lepidotperta: Lymantriidae) populations in the Appalachian Mountains. Journal of Economic Entomology, 90, 1259-1266.

Talbot, P.H.B. (1977) The Sirex-Amylostereum-Pinus association. Annual Review of Phytopathology, 15, 41-54.

Williams, D.T., Straw, N., Townsend, M., Wilkinson, A.S. \& Mullins, A. (2013) Monitoring oak processionary moth Thaumetopoea processionea L. using pheromone traps: the influence of pheromone lure source, trap design and height above the ground on capture rates. Agricultural and Forest Entomology, 15, 126-134.

Witzgall, P., Kirsch, P. \& Cork, A. (2010) Sex pheromones and their impact on pest management. Journal of Chemical Ecology, 36, $80-100$.

Accepted 16 June 2014

First published online 2 September 2014 